In cooperation with the Rocky Mountain Golf Course Superintendents Association

\title{
Estimated Colorado Golf Course Irrigation Water Use, 2005
}

Open-File Report 2008-1267 



\section{Estimated Colorado Golf Course Irrigation Water Use, 2005}

By Tamara Ivahnenko

In cooperation with the Rocky Mountain Golf Course Superintendents Association

Open-File Report 2008-1267 


\title{
U.S. Department of the Interior \\ KEN SALAZAR, Secretary
}

\author{
U.S. Geological Survey \\ Suzette M. Kimball, Acting Director
}

U.S. Geological Survey, Reston, Virginia: 2009

For product and ordering information:

World Wide Web: http://www.usgs.gov/pubprod

Telephone: 1-888-ASK-USGS For more information on the USGS—-the Federal source for science about the Earth,
its natural and living resources, natural hazards, and the environment:
World Wide Web: http://www.usgs.gov
Telephone: 1-888-ASK-USGS
Any use of trade, product, or firm names is for descriptive purposes only and does not imply endorsement
by the U.S. Government.
Although this report is in the public domain, permission must be secured from the individual copyright owners to
reproduce any copyrighted materials contained within this report.

Suggested citation:

Ivahnenko, Tamara, 2009, Estimated Colorado golf course irrigation water use, 2005: U.S. Geological Survey Open-File Report 2008-1267, 25 p. 


\section{Contents}

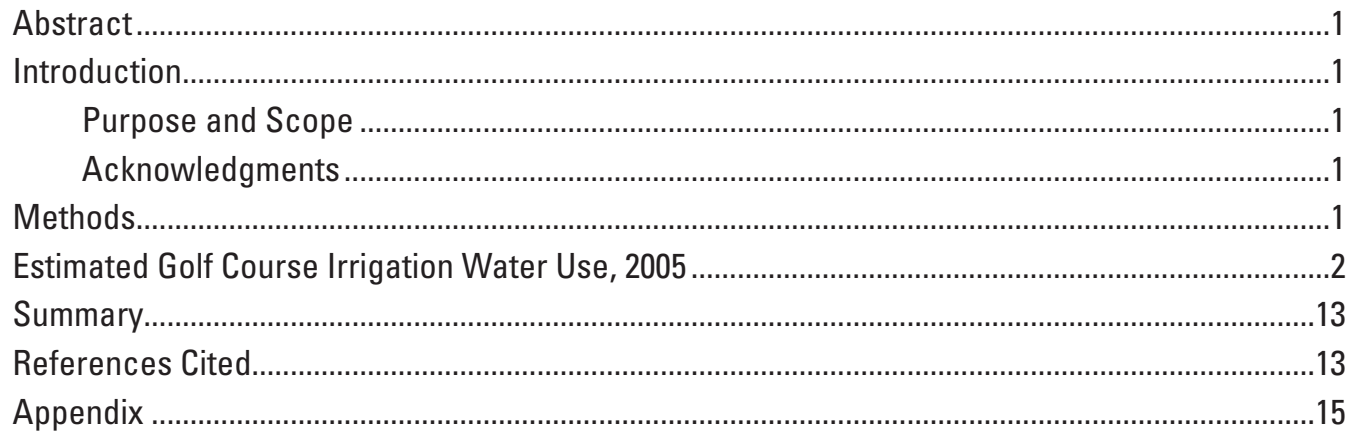

\section{Figures}

1. Map showing total golf course irrigation water use, by Colorado county, 2005...............5

2. Graph showing estimated golf course irrigation water use in 2005 and number

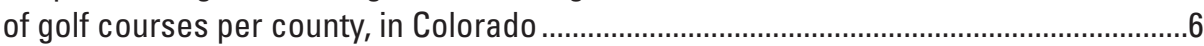

3. Map showing surface-water golf course irrigation water use, by Colorado

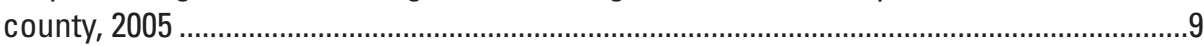

4. Map showing ground-water golf course irrigation water use, by Colorado county, 2005 ..............................................................................................................

5. Map showing potable (public supply) water golf course irrigation water use, by Colorado county, 2005

6. Map showing reclaimed water golf course irrigation water use, by Colorado county, 2005

\section{Tables}

1. Number of golf courses, by source water type, by Colorado county, 2005 .......................3

2. Estimated golf course irrigation water use, by source water type, and irrigated acres by Colorado county, 2005........................................................................................ 


\section{Conversion Factors}

\begin{tabular}{|c|c|c|}
\hline Multiply & By & To obtain \\
\hline \multicolumn{3}{|c|}{ Area } \\
\hline acre & 4,047 & square meter $\left(\mathrm{m}^{2}\right)$ \\
\hline acre & 0.4047 & hectare (ha) \\
\hline acre & 0.4047 & square hectometer $\left(\mathrm{hm}^{2}\right)$ \\
\hline acre & 0.004047 & square kilometer $\left(\mathrm{km}^{2}\right)$ \\
\hline section (640 acres or 1 square mile) & 259.0 & square hectometer $\left(\mathrm{hm}^{2}\right)$ \\
\hline square mile $\left(\mathrm{mi}^{2}\right)$ & 259.0 & hectare (ha) \\
\hline square mile $\left(\mathrm{mi}^{2}\right)$ & 2.590 & square kilometer $\left(\mathrm{km}^{2}\right)$ \\
\hline \multicolumn{3}{|c|}{ Volume } \\
\hline gallon (gal) & 3.785 & liter $(\mathrm{L})$ \\
\hline million gallons (Mgal) & 3,785 & cubic meter $\left(\mathrm{m}^{3}\right)$ \\
\hline acre-foot (acre-ft) & 1,233 & cubic meter $\left(\mathrm{m}^{3}\right)$ \\
\hline acre-foot (acre-ft) & 0.001233 & cubic hectometer $\left(\mathrm{hm}^{3}\right)$ \\
\hline \multicolumn{3}{|c|}{ Flow rate } \\
\hline million gallons per day (Mgal/d) & 0.04381 & cubic meter per second $\left(\mathrm{m}^{3} / \mathrm{s}\right)$ \\
\hline
\end{tabular}




\title{
Estimated Colorado Golf Course Irrigation Water Use, 2005
}

\author{
By Tamara Ivahnenko
}

\begin{abstract}
Golf course irrigation water-use data were collected as part of the U.S. Geological Survey National Water Use Program's 2005 compilation to provide baseline information, as no golf course irrigation water-use data (separate from crop irrigation) have been reported in previous compilations. A Web-based survey, designed by the U.S. Geological Survey, in cooperation with the Rocky Mountain Golf Course Superintendents Association (RMGCSA), was electronically distributed by the association to the 237 members in Colorado. Forty-three percent of the members returned the survey, and additional source water information was collected by telephone for all but 20 of the 245 association member and non-member Colorado golf courses.

For golf courses where no data were collected at all, an average "per hole" coefficient, based on returned surveys from that same county, were applied. In counties where no data were collected at all, a State average "per hole" value of 13.2 acre-feet was used as the coefficient. In 2005, Colorado had 243 turf golf courses (there are 2 sand courses in the State) that had an estimated 2.27 acre-feet per irrigated course acre, and 65 percent of the source water for these courses was surface water. Ground water, potable water (public supply), and reclaimed wastewater, either partially or wholly, were source waters for the remaining courses. Fifty-three of the 64 counties in Colorado have at least one golf course, with the greatest number of courses in Jefferson ( 23 courses), Arapahoe (22 courses), and El Paso Counties (20 courses). In 2005, an estimated 5,647.8 acre-feet in Jefferson County, 5,402 acre-feet in Arapahoe County, and 4,473.3 acre-feet in El Paso County were used to irrigate the turf grass.
\end{abstract}

\section{Introduction}

Golf has been formally played in Colorado since 1895 , when the City of Denver opened the first 18-hole course in the State at Overland Park (originally the Denver Country Club) (National Golf Foundation, 2006; Goodstein, 2007). Since then, 244 more courses have been added, with 8 more scheduled to open between 2006 and 2008. Little or no golf course irrigation data have been collected from these courses as part of the U.S. Geological Survey's (USGS) National Water Use Program's compilations since the inception of the compilations in 1950. As part of the 2005 Colorado water-use compilation, the USGS, in cooperation with the Rocky Mountain Golf Course Superintendents Association (RMGCSA), distributed a Web-based water-use survey to the association's 237 Colorado members. This report summarizes the results, at the State and county levels, of the 2005 survey as well as the estimated water usage for the courses where no survey was returned.

\section{Purpose and Scope}

The purpose of this report is to provide a summary of golf course irrigation data to the RMGCSA. The data were collected as part of the USGS 2005 National Water Use Program compilation to provide baseline information, as no golf course irrigation water-use information (separate from crop irrigation) has been reported in previous compilations. Only 2005 survey results and estimated State and county-level irrigation golf course data from the 245 courses in Colorado are discussed, with no water-use information on any single course presented (except in counties that contain a single golf course).

\section{Acknowledgments}

The author would like to thank Joe McCleary, past President of the RMGCSA, for his cooperation and assistance in designing the Web-based irrigation water-use survey, and distributing the survey URL to the RMGCSA members. The author also thanks all the association members who completed the survey either online or by telephone and who provided valuable information on Colorado golf course irrigation and maintenance.

\section{Methods}

A Web-based survey, designed by the USGS in cooperation with the RMGCSA, was electronically distributed to all the RMGCSA members in Colorado. This survey (Appendix) queried the members for basic golf course information (location, contact information, irrigated acres), identification of source water type (ground water, surface water, purchased potable water [treated public-supply] or reclaimed water) and total amount of water withdrawn from each source type in 2005. 
Of the 237 golf courses with superintendents as members of the RMGCSA, 101 (43 percent) surveys were returned (both electronically and by telephone). At least one golf course survey was returned from nearly every county in which a golf course is located (the exceptions are Chaffee, Elbert, Montezuma, Ouray, Prowers, Teller, Saguache, and Sedgwick Counties). Golf course information (date established, number of holes, contact information) was obtained from the 2006 Golf Course Directory (National Golf Foundation, 2006). Springfield Golf Course (Baca County) and Hugo Golf Course (Lincoln County) are not included in the statistics, as these are sand courses (no turf) and use little or no water for irrigation. During the telephone surveys, source water types for other courses in the same county were queried, especially if the course survey had not been completed. Source water information (necessary information for estimating irrigation water use) was collected for all but 20 golf courses. County information, either from returned surveys or telephone calls, was used to infer water source types for those 20 courses.

To estimate the amount of water used for irrigation in 2005 for the 142 golf courses, with no survey information, a "per hole" value was used. Because information was lacking on total irrigated acres for any course that did not return a survey, this method offered a baseline from which to start water-use estimates. These "per hole" values were calculated on the basis of returned survey information and were applied by county to other courses in the same county, thereby ensuring estimated values based on similar environmental factors, although not necessarily similar irrigation practices. In counties where no surveys were returned, a State average "per hole" value of 13.2 acre-feet (acre-ft) was used as the coefficient.

\section{Estimated Golf Course Irrigation Water Use, 2005}

In 2005, Colorado had 243 turf golf courses and an estimated 2.27 acre-ft per irrigated course acre. Approximately 24,800 acres in Colorado were irrigated course turf. Surface water, ground water, potable (public supply) water, and reclaimed wastewater are the four source water types in Colorado. In 13.5 percent of courses statewide, irrigation water was obtained from a mixture of these sources. Surface water is the predominant source, and provides either partially or wholly, 66 percent of irrigation water. Ground water provided 15 percent, while reclaimed wastewater and potable public supply provided 11 and 8 percent of the irrigation water, respectively.

Fifty-three of the 64 counties in Colorado have at least one golf course (table 1), with the greatest number of courses in Jefferson (23 courses), Arapahoe (22 courses), and El Paso Counties (20 courses). Total irrigation water use by county reflects the number of courses in that county, as illustrated in figure 1. In 2005, an estimated 5,647.8 acre-ft in Jefferson County, 5,402 acre-ft in Arapahoe County and 4,473.3 acre-ft in El Paso County were used to irrigate the turf grass. However, there are a few outlying data points based on the number of courses per county (fig. 2, table 1). Summit County, which has five courses, had an estimated 544 acre-ft of irrigation water use, a use value closer to the counties that have two to three courses. Boulder County, however, had 11 courses in 2005 and used an estimated 1,946.7 acre-ft, a use closer to counties having 6 to 8 courses. Fremont County had an estimated water use of 1,098.6 acre-ft, a use about 2 to 3 times higher than other counties with two courses. The variation in water use in counties may be due to environmental (precipitation, soil types, temperature) and anthropogenic (irrigation and xeriscape practices, turf species, number of acres irrigated) factors. 
Table 1. Number of golf courses, by source water type, by Colorado county, 2005.

[SW, surface water; GW, ground water; PPW, purchased potable water; RWW, reclaimed wastewater; Number of golf courses by source water type does not add to total number of courses due to multiple source water types used by some golf courses in that county; Baca and Lincoln Counties each have a sand course not included in statistics, as little irrigation takes place on these courses]

\begin{tabular}{|c|c|c|c|c|c|}
\hline \multirow{2}{*}{ County } & \multicolumn{4}{|c|}{ Number of golf courses by source water type } & \multirow{2}{*}{$\begin{array}{l}\text { Total number of } \\
\text { courses }\end{array}$} \\
\hline & Sw & GW & PPW & RWW & \\
\hline Adams & 4 & 2 & 0 & 4 & 9 \\
\hline Alamosa & 1 & 0 & 1 & 0 & 1 \\
\hline Arapahoe & 7 & 13 & 5 & 6 & 22 \\
\hline Archuleta & 1 & 0 & 0 & 0 & 1 \\
\hline Baca & 0 & 0 & 0 & 0 & 1 \\
\hline Bent & 1 & 0 & 0 & 0 & 1 \\
\hline Boulder & 10 & 0 & 1 & 1 & 11 \\
\hline Broomfield & 2 & 0 & 1 & 1 & 4 \\
\hline Chaffee & 2 & 0 & 1 & 0 & 2 \\
\hline Cheyenne & 0 & 1 & 0 & 0 & 1 \\
\hline Custer & 1 & 0 & 0 & 0 & 1 \\
\hline Delta & 2 & 0 & 0 & 0 & 2 \\
\hline Denver & 5 & 3 & 5 & 3 & 9 \\
\hline Douglas & 1 & 9 & 2 & 5 & 15 \\
\hline Eagle & 15 & 0 & 0 & 0 & 15 \\
\hline Elbert & 1 & 0 & 0 & 0 & 1 \\
\hline El Paso & 8 & 7 & 3 & 7 & 20 \\
\hline Fremont & 2 & 0 & 0 & 0 & 2 \\
\hline Garfield & 8 & 0 & 0 & 0 & 8 \\
\hline Grand & 4 & 0 & 0 & 0 & 4 \\
\hline Gunnison & 2 & 0 & 0 & 0 & 2 \\
\hline Huerfano & 2 & 0 & 0 & 0 & 2 \\
\hline Jefferson & 21 & 2 & 2 & 2 & 23 \\
\hline Kiowa & 0 & 1 & 0 & 0 & 1 \\
\hline Kit Carson & 0 & 2 & 0 & 1 & 3 \\
\hline Lake & 0 & 1 & 0 & 0 & 1 \\
\hline La Plata & 3 & 2 & 0 & 1 & 4 \\
\hline Larimer & 13 & 1 & 0 & 0 & 14 \\
\hline Las Animas & 0 & 0 & 1 & 0 & 1 \\
\hline
\end{tabular}


Table 1. Number of golf courses, by source water type, by Colorado county, 2005.-Continued

[SW, surface water; GW, ground water; PPW, purchased potable water; RWW, reclaimed wastewater; Number of golf courses by source water type does not add to total number of courses due to multiple source water types used by some golf courses in that county; Baca and Lincoln Counties each have a sand course not included in statistics, as little irrigation takes place on these courses]

\begin{tabular}{|c|c|c|c|c|c|}
\hline \multirow{2}{*}{ County } & \multicolumn{4}{|c|}{ Number of golf courses by source water type } & \multirow{2}{*}{$\begin{array}{l}\text { Total number of } \\
\text { courses }\end{array}$} \\
\hline & SW & GW & PPW & RWW & \\
\hline Lincoln & 0 & 1 & 0 & 0 & 2 \\
\hline Logan & 0 & 2 & 0 & 0 & 2 \\
\hline Mesa & 6 & 0 & 0 & 0 & 6 \\
\hline Moffat & 1 & 0 & 0 & 0 & 1 \\
\hline Montezuma & 1 & 0 & 0 & 0 & 1 \\
\hline Montrose & 4 & 0 & 2 & 0 & 4 \\
\hline Morgan & 0 & 2 & 0 & 0 & 2 \\
\hline Otero & 1 & 1 & 1 & 0 & 3 \\
\hline Ouray & 1 & 0 & 0 & 0 & 1 \\
\hline Phillips & 1 & 1 & 0 & 0 & 2 \\
\hline Pitkin & 3 & 0 & 0 & 0 & 3 \\
\hline Prowers & 0 & 0 & 1 & 0 & 1 \\
\hline Pueblo & 2 & 0 & 2 & 1 & 5 \\
\hline Rio Blanco & 2 & 0 & 0 & 0 & 2 \\
\hline Rio Grande & 1 & 0 & 1 & 0 & 2 \\
\hline Routt & 4 & 1 & 1 & 0 & 4 \\
\hline Saguache & 0 & 1 & 0 & 0 & 1 \\
\hline San Miguel & 1 & 0 & 0 & 0 & 1 \\
\hline Sedgwick & 0 & 1 & 0 & 0 & 1 \\
\hline Summit & 5 & 1 & 0 & 0 & 5 \\
\hline Teller & 1 & 0 & 0 & 0 & 1 \\
\hline Washington & 0 & 1 & 0 & 0 & 1 \\
\hline Weld & 7 & 0 & 2 & 1 & 10 \\
\hline Yuma & 0 & 1 & 2 & 0 & 3 \\
\hline Total & 157 & 57 & 34 & 33 & 245 \\
\hline
\end{tabular}




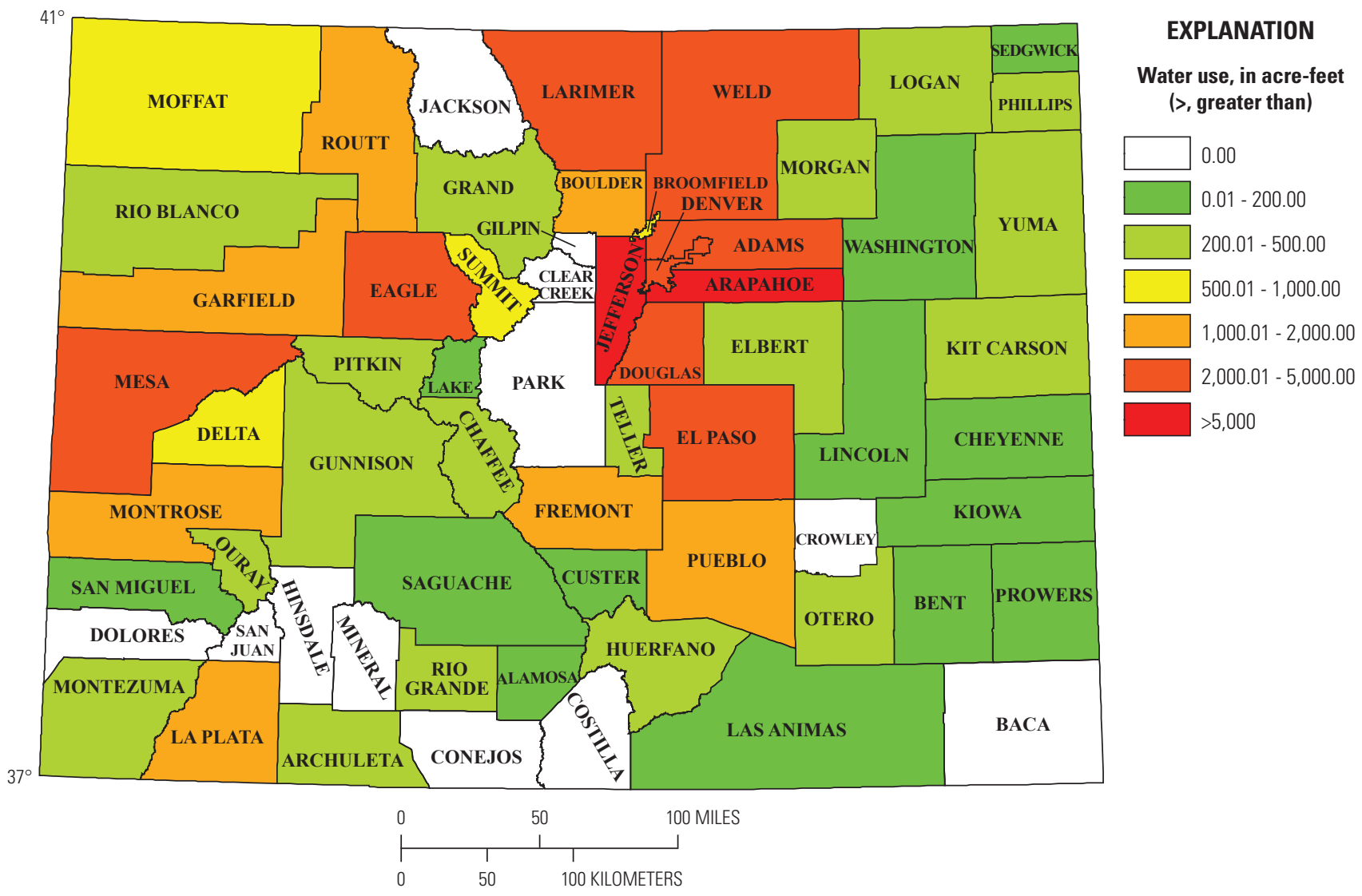

Figure 1. Total golf course irrigation water use, by Colorado county, 2005. 


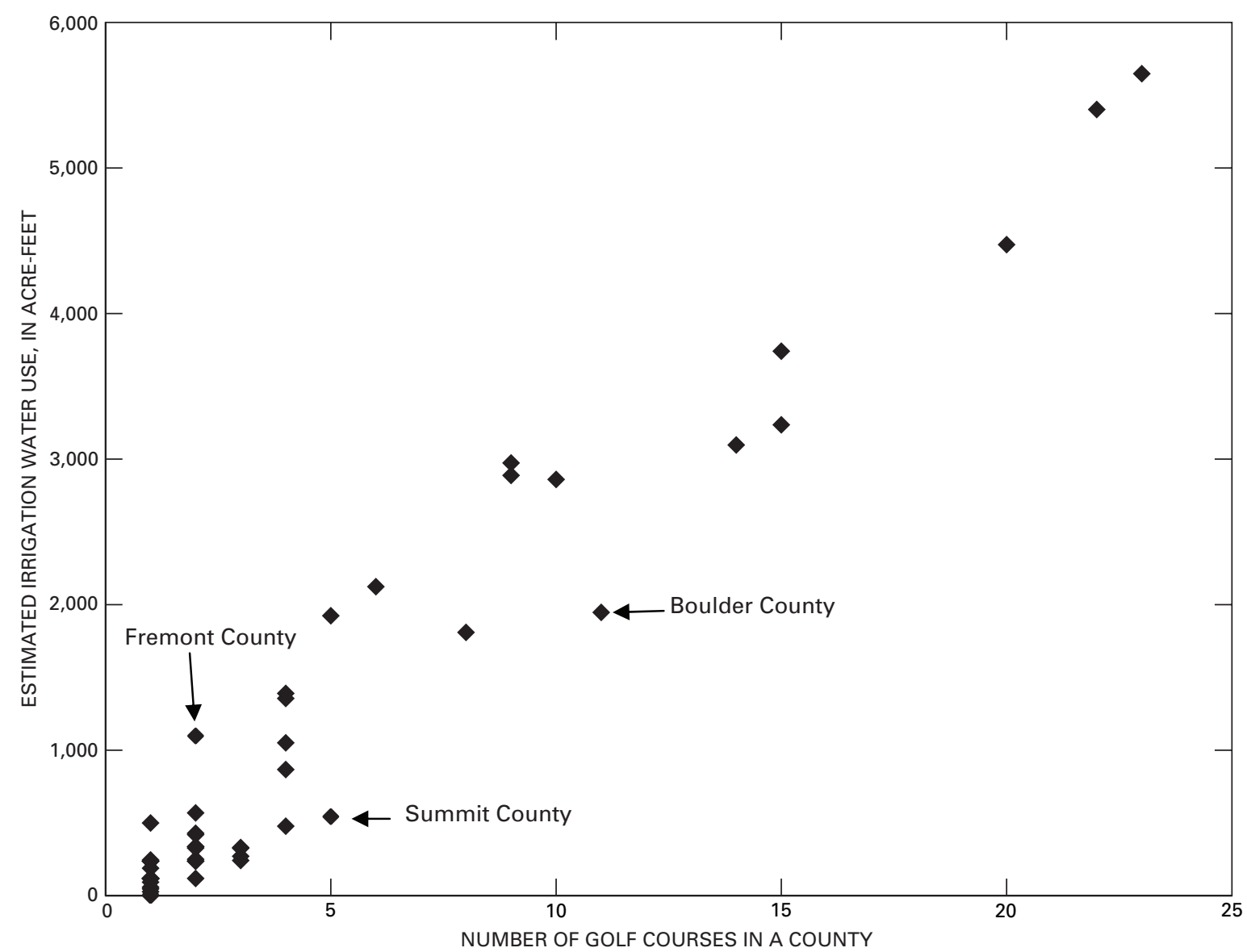

Figure 2. Estimated golf course irrigation water use in 2005 and number of golf courses per county, in Colorado.

In total, 39 counties use surface water as an irrigation source, and the use of surface water for golf course irrigation was greatest in Jefferson, Eagle, Larimer, Weld, and Mesa Counties (table 2 and fig. 3). Nineteen of those 39 counties report surface water as the sole source water type for golf course irrigation (table 2). Ground-water resources are used for irrigation in 23 counties, with the greatest uses in Arapahoe, Douglas, and El Paso Counties (table 2, fig. 4). The Arapahoe aquifer (a part of the Denver Basin aquifer system) is the most frequently tapped aquifer as determined from the returned surveys (unpublished data on file at U.S. Geological Survey, Pueblo Colorado office). Eight counties (Cheyenne, Kiowa, Lake, Lincoln, Logan, Morgan, Sedgwick, and Washington) have ground water as the only source water type for golf course irrigation. Potable (public supply) water use is greatest in Douglas, Pueblo, and Arapahoe Counties, respectively (table 2, fig. 5); but of all of the 18 counties that use potable water for irrigation, only Prowers and Las Animas Counties use this water type as the sole source (table 1). Finally, golf courses in 12 of the 53 counties provided estimated use of reclaimed water, and the greatest reported uses were in El Paso, Arapahoe, Denver, Adams and Douglas Counties (table 2, fig. 6). In all 12 counties, reclaimed water use for irrigation is not a sole source water type, but is used as a supplement to one of the other three source water types (table 1). 
Table 2. Estimated golf course irrigation water use, by source water type, and irrigated acres by Colorado county, 2005.

[SW, surface water; GW, ground water; PPW, purchased potable water; RWW, reclaimed wastewater]

\begin{tabular}{|c|c|c|c|c|c|c|}
\hline \multirow{2}{*}{ County } & \multicolumn{4}{|c|}{$\begin{array}{l}\text { Total estimated irrigation water use by source type } \\
\text { (acre-feet) }\end{array}$} & \multirow{2}{*}{$\begin{array}{l}\text { Total estimated } \\
\text { irrigation water } \\
\text { use (acre-feet) }\end{array}$} & \multirow{2}{*}{$\begin{array}{c}\text { Estimated } \\
\text { irrigated acres }\end{array}$} \\
\hline & sw & GW & PPW & RWW & & \\
\hline Adams & $1,336.2$ & 834.7 & 0 & 803.0 & 2974 & 1,024 \\
\hline Alamosa & 90.8 & 0 & 98.3 & 0 & 189.1 & 75 \\
\hline Arapahoe & $1,864.0$ & $1,880.6$ & 480.6 & $1,176.8$ & 5,402 & 2,240 \\
\hline Archuleta & 246.3 & 0 & 0 & 0 & 246.3 & 150 \\
\hline Bent & 119.2 & 0 & 0 & 0 & 119.2 & 48 \\
\hline Boulder & $1,730.1$ & 0 & 92.7 & 123.9 & $1,946.7$ & 1,365 \\
\hline Broomfield & 268.6 & 0 & 273.3 & 325.2 & 867.1 & 314 \\
\hline Chaffee & 214.5 & 0 & 24.2 & 0 & 238.3 & 97 \\
\hline Cheyenne & 0 & 119.2 & 0 & 0 & 119.2 & 48 \\
\hline Custer & 9.2 & 0 & 0 & 0 & 9.2 & 60 \\
\hline Delta & 569.6 & 0 & 0 & 0 & 569.6 & 205 \\
\hline Denver & $1,292.4$ & 330.5 & 448.5 & 816.4 & $2,887.8$ & 1,182 \\
\hline Douglas & 145.2 & 1526.2 & 1045.3 & 519.0 & $3,235.7$ & 1,589 \\
\hline Eagle & $3,741.8$ & 0 & 0 & 0 & $3,741.8$ & 1,675 \\
\hline Elbert & 238.3 & 0 & 0 & 0 & 238.3 & 97 \\
\hline El Paso & $1,570.6$ & $1,037.3$ & 338.6 & $1,526.8$ & $4,473.3$ & 2,814 \\
\hline Fremont & $1,098.6$ & 0 & 0 & 0 & $1,098.6$ & 240 \\
\hline Garfield & $1,809.4$ & 0 & 0 & 0 & $1,809.4$ & 630 \\
\hline Grand & 478.0 & 0 & 0 & 0 & 478.0 & 425 \\
\hline Gunnison & 336.4 & 0 & 0 & 0 & 336.4 & 185 \\
\hline Huerfano & 327.4 & 0 & 0 & 0 & 327.4 & 120 \\
\hline Jefferson & $4,651.3$ & 406.9 & 239.5 & 350.1 & $5,647.8$ & 2,533 \\
\hline Kiowa & 0 & 119.2 & 0 & 0 & 119.2 & 48 \\
\hline Kit Carson & 0 & 238.3 & 0 & 3.9 & 242.3 & 30 \\
\hline Lake & 0 & 28.3 & 0 & 0 & 28.3 & 23 \\
\hline La Plata & 466.8 & 466.8 & 0 & 116.7 & $1,050.4$ & 385 \\
\hline Larimer & $2,961.3$ & 134.6 & 0 & 0 & $3,096.6$ & 1,466 \\
\hline Las Animas & 0 & 0 & 47.5 & 0 & 47.5 & 34 \\
\hline Lincoln & 0 & 119.2 & 0 & 0 & 119.2 & 48 \\
\hline Logan & 0 & 430 & 0 & 0 & 430 & 110 \\
\hline Mesa & $2,123.3$ & 0 & 0 & 0 & $2,123.3$ & 888 \\
\hline
\end{tabular}


Table 2. Estimated golf course irrigation water use, by source water type, and irrigated acres by Colorado county, 2005.-Continued

[SW, surface water; GW, ground water; PPW, purchased potable water; RWW, reclaimed wastewater]

\begin{tabular}{|c|c|c|c|c|c|c|}
\hline \multirow{2}{*}{ County } & \multicolumn{4}{|c|}{$\begin{array}{l}\text { Total estimated irrigation water use by source type } \\
\text { (acre-feet) }\end{array}$} & \multirow{2}{*}{$\begin{array}{l}\text { Total estimated } \\
\text { irrigation water } \\
\text { use (acre-feet) }\end{array}$} & \multirow{2}{*}{$\begin{array}{c}\text { Estimated } \\
\text { irrigated acres }\end{array}$} \\
\hline & SW & GW & PPW & RWW & & \\
\hline Moffat & 500.2 & 0 & 0 & 0 & 500.2 & 165 \\
\hline Montezuma & 238.3 & 0 & 0 & 0 & 238.3 & 97 \\
\hline Montrose & $1,384.9$ & 0 & 4.9 & 0 & $1,389.8$ & 350 \\
\hline Morgan & 0 & 420.5 & 0 & 0 & 420.5 & 185 \\
\hline Otero & 109 & 98.1 & 119.8 & 0 & 326.9 & 98 \\
\hline Ouray & 238.3 & 0 & 0 & 0 & 238.3 & 97 \\
\hline Phillips & 119.2 & 119.2 & 0 & 0 & 238.4 & 97 \\
\hline Pitkin & 271.8 & 0 & 0 & 0 & 271.8 & 225 \\
\hline Prowers & 0 & 0 & 116.4 & 0 & 116.4 & 48 \\
\hline Pueblo & 921.4 & 0 & 633.9 & 368.6 & $1,923.8$ & 847 \\
\hline Rio Blanco & 337.8 & 0 & 0 & 0 & 337.8 & 110 \\
\hline Rio Grande & 170.2 & 0 & 79.9 & 0 & 250.1 & 149 \\
\hline Routt & $1,346.8$ & 7.0 & 2.0 & 0 & $1,355.9$ & 385 \\
\hline Saguache & 119.2 & 0 & 0 & 0 & 119.2 & 48 \\
\hline San Miguel & 93.1 & 0 & 0 & 0 & 93.1 & 75 \\
\hline Sedgwick & 0 & 119.2 & 0 & 0 & 119.2 & 48 \\
\hline Summit & 490.5 & 53.6 & 0 & 0 & 544.1 & 385 \\
\hline Teller & 238.3 & 0 & 0 & 0 & 238.3 & 97 \\
\hline Washington & 0 & 59.0 & 0 & 0 & 59.0 & 25 \\
\hline Weld & $2,612.4$ & 0 & 217.5 & 30.0 & $2,859.9$ & 1017 \\
\hline Yuma & 0 & 110.6 & 221.1 & 0 & 331.7 & 105 \\
\hline Total & $36,881.5$ & $8,658.7$ & $4,484.0$ & $6,160.5$ & $56,184.2$ & 24,800 \\
\hline
\end{tabular}




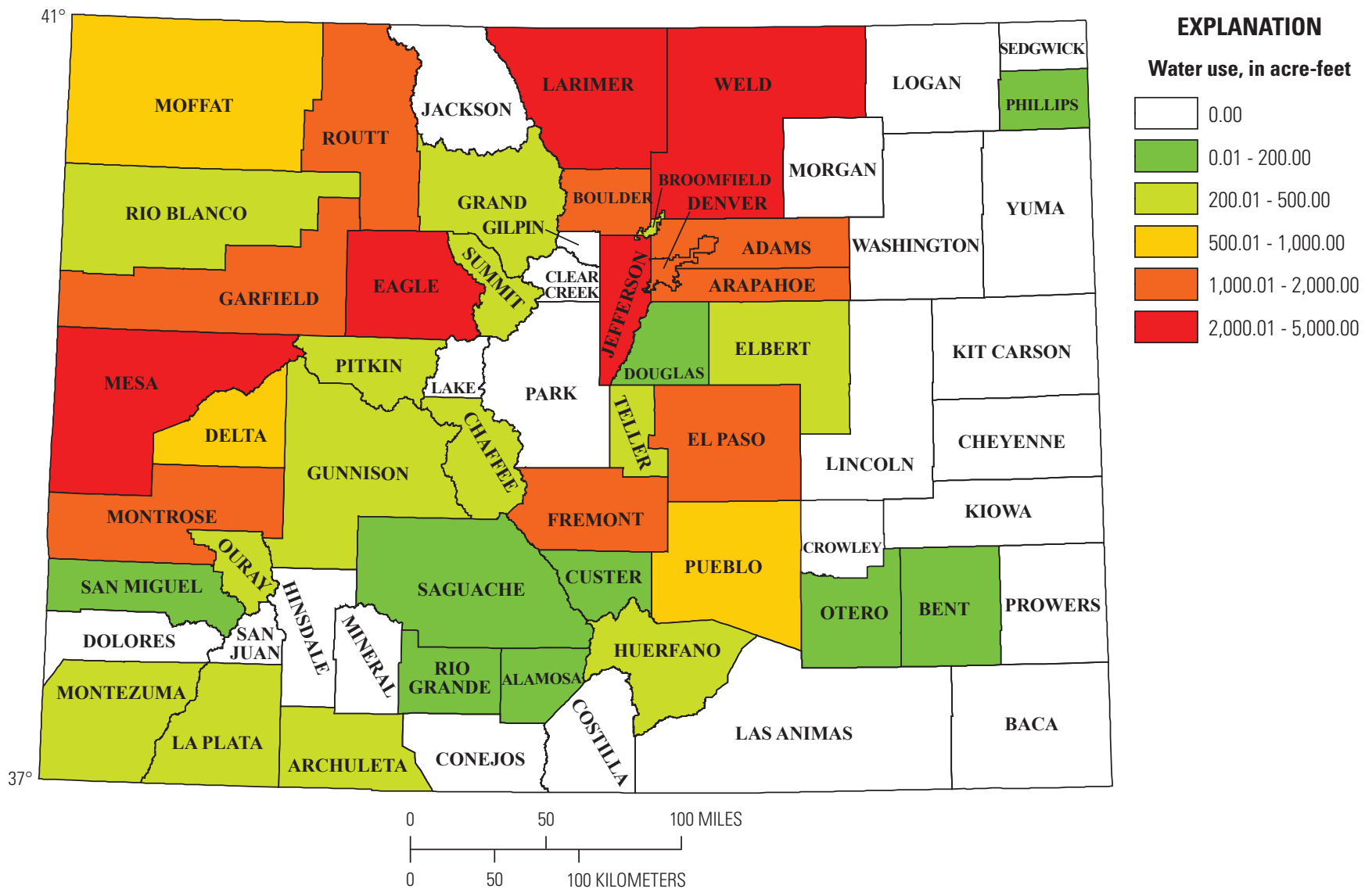

Figure 3. Surface-water golf course irrigation water use, by Colorado county, 2005. 


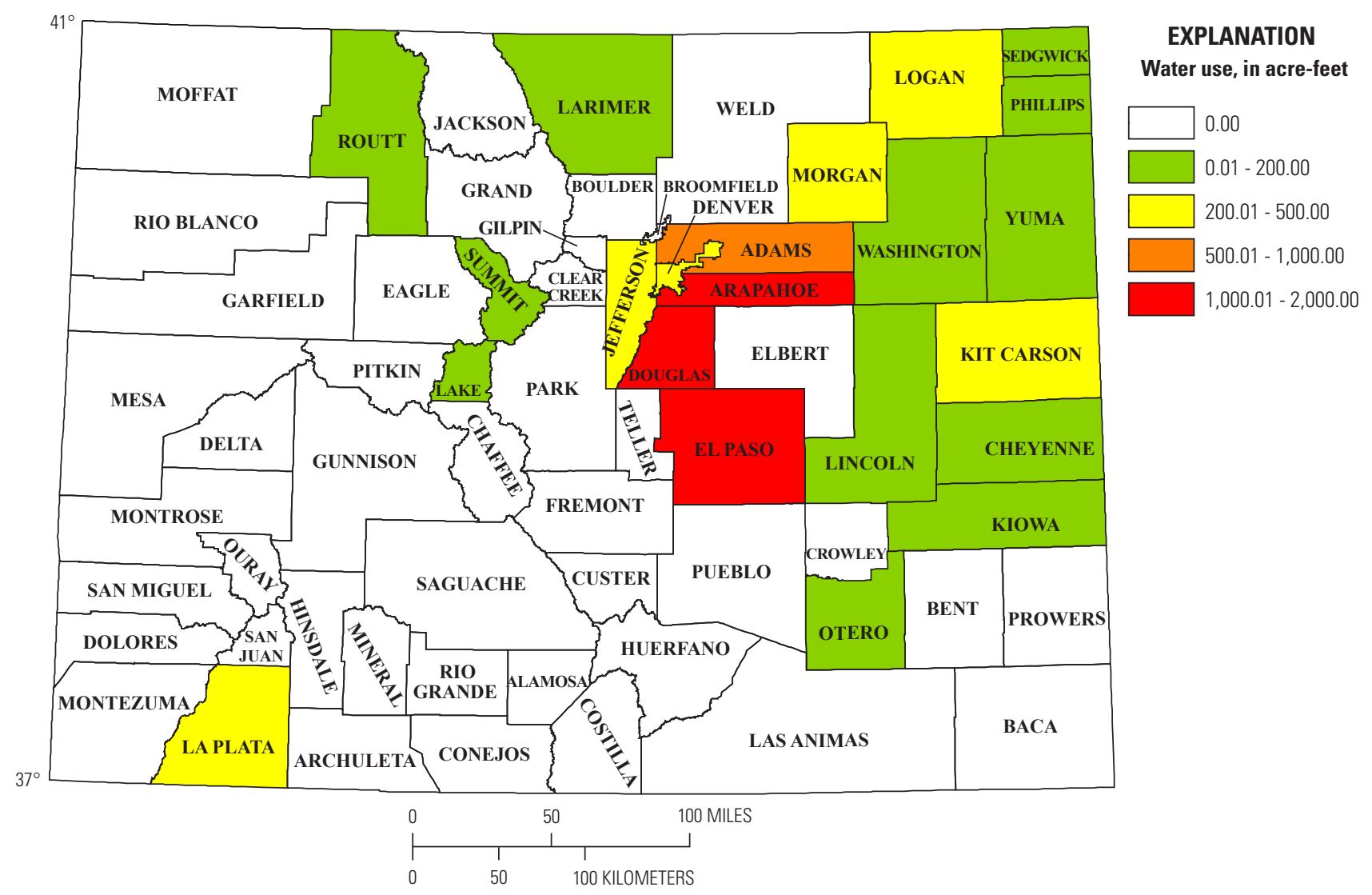

Figure 4. Ground-water golf course irrigation water use, by Colorado county, 2005. 


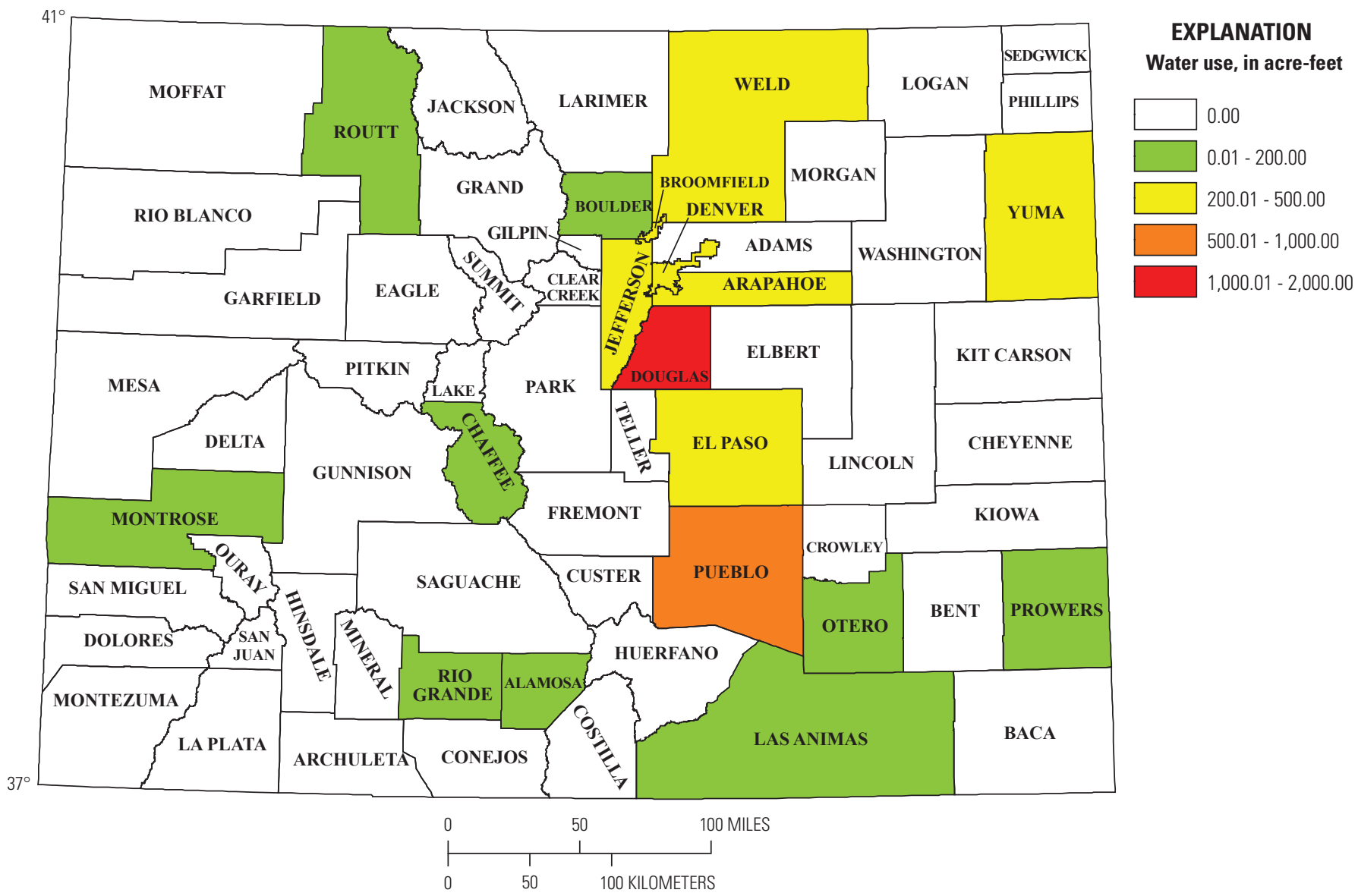

Figure 5. Potable (public-supply) water golf course irrigation water use, by Colorado county, 2005. 


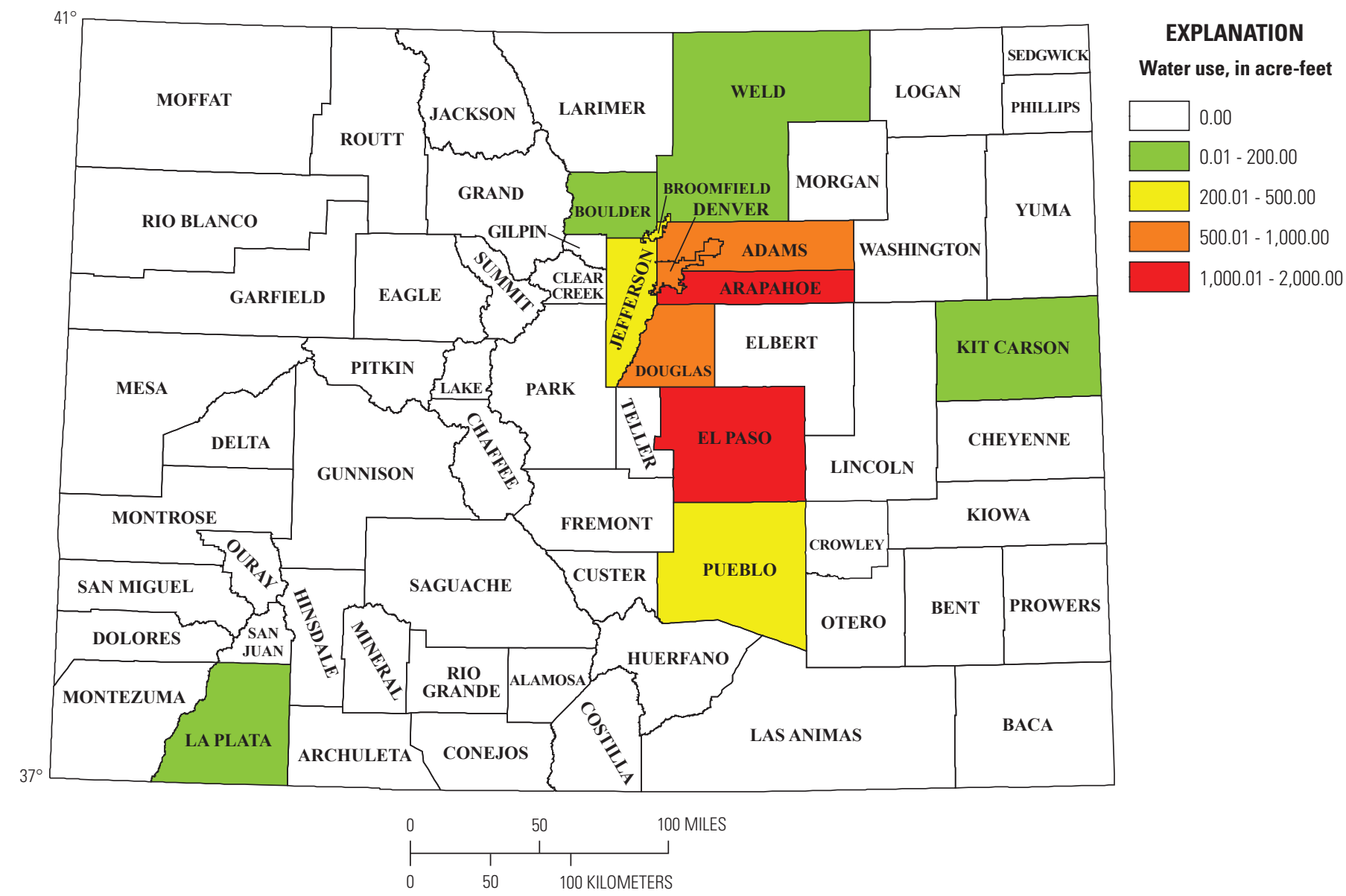

Figure 6. Reclaimed water golf course irrigation water use, by Colorado county, 2005. 


\section{Summary}

Golf course irrigation water-use data were collected as part of the U.S. Geological Survey National Water Use Program's 2005 compilation to provide baseline information, as no golf course irrigation water-use information (separate from crop irrigation) has been reported in previous U.S. Geological Survey compilations. A Web-based survey, designed by the U.S. Geological Survey, in cooperation with the Rocky Mountain Golf Course Superintendents Association, was electronically distributed by the association to the 237 members in Colorado. Forty-three percent of the members returned the survey, and additional source water information was collected by telephone for all but 20 of the 245 association member and non-member golf courses. Source water for these 20 courses was inferred from returned survey and county information.

To estimate the amount of water used for irrigation in 2005 for the 142 golf courses, a "per hole" coefficient was used. These "per hole" values were calculated on the basis of returned survey information and were applied by county to other courses in the same county. In counties where no surveys were returned, a State average "per hole" value of 13.2 acrefeet was used as the coefficient.

In 2005, Colorado had 243 turf golf courses across the State that had an estimated 2.27 acre-ft per irrigated course acre, and 66 percent of the source water for these courses was surface water. Approximately 24,800 acres of course turf in 2005 were irrigated. Springfield Golf Course (Baca County) and Hugo Golf Course (Lincoln County) are not included in the statistics, as these are sand courses (no turf) and use little or no water for irrigation.

Ground water (15 percent), reclaimed wastewater (11 percent), and potable (public supply) water (8 percent), either partially or wholly, were tapped for the remaining water use. Fifty-three of the 64 counties in Colorado have at least one golf course, with the greatest number of courses in Jefferson ( 23 courses), Arapahoe (22 courses), and El Paso Counties (20 courses). In 2005, an estimated 5,647.8 acre-ft of water in Jefferson County, 5,402 acre-ft in Arapahoe County and 4,473.3 acre-ft in El Paso County were used to irrigate the turf grass.

\section{References Cited}

Goodstein, Phillip, 2007, Review of "The History of the Denver Country Club (1887-2006)," by Charles C. Bonniewell and David F. Haalas: Colorado Historical Society, http://192.70.175.134/publications/reviews.htm, accessed December 20, 2007.

National Golf Foundation, 2006, Golf course directory, Jupiter, Florida, National Golf Foundation. 
Publishing support provided by:

Denver Publishing Service Center

For more information concerning this publication, contact: Director, USGS Colorado Water Science Center

Box 25046, Mail Stop 415

Denver, CO 80225

(303)236-4882

Or visit the Colorado Water Science Center Web site at: http://co.water.usgs.gov/

1-888-ASK-USGS 


\section{Appendix. The Web-based survey distributed by the U.S. Geological Survey, in cooperation with the Rocky Mountain Golf Course Superintendents Association, in 2005.}




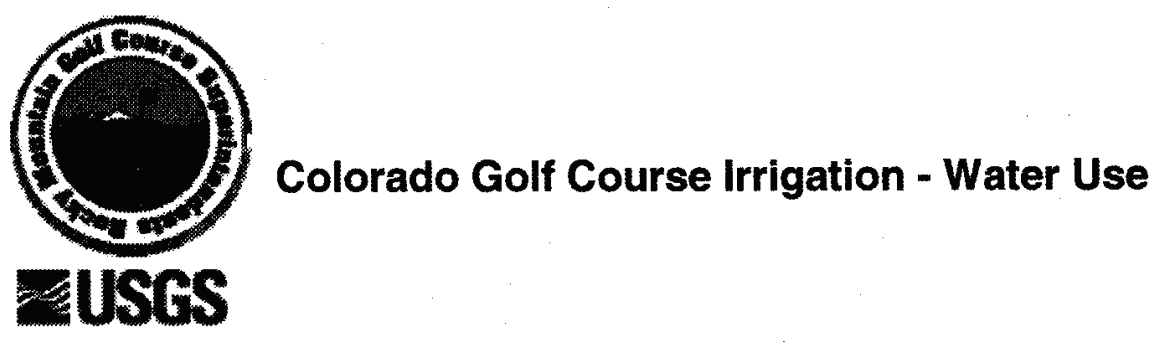

1

General Golf Course Information

Name of Golf

Course:

County Location:

Contact Person:

Title:

Telephone:

sUPMIT

Survey Page 1

2

Golf Course Area

Number of Acres

Total:

Number of Acres

Irrigated:

Number of Acres

of Tees:

Number of Acres

of Greens: 
Number of Acres of Fairways:

Number of Acres of Rough:

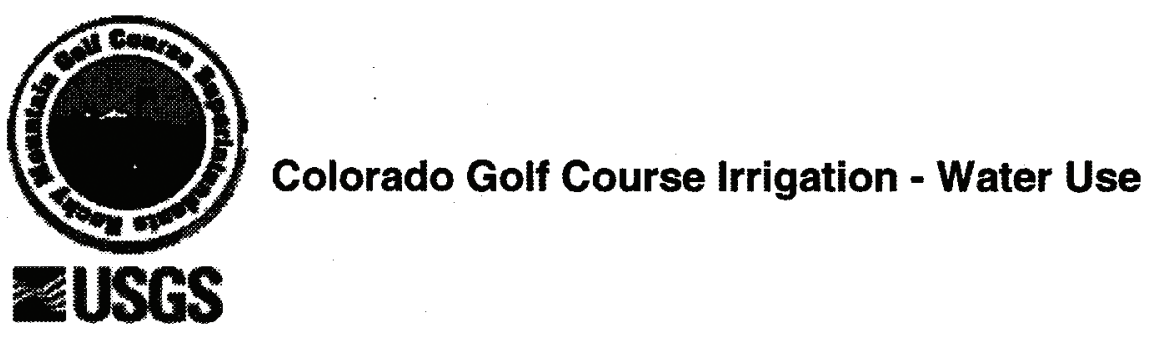

Surface Water Sources

SUEMIT 
Surface Water Source(s) - (Enter up to two surface water sources)

4

Surface Water Source 1

Name of Source 1:

Amount (total

gallons used in

2005 or specify

units):

5

Above Source is:

- Primary

- Secondary

Certiary

6

Surface Water Source 2

Name of Source 2:

Amount (total

gallons used in

2005 or specify

units):

7

Above Source is:

- Primary

Secondary

Tertiary 


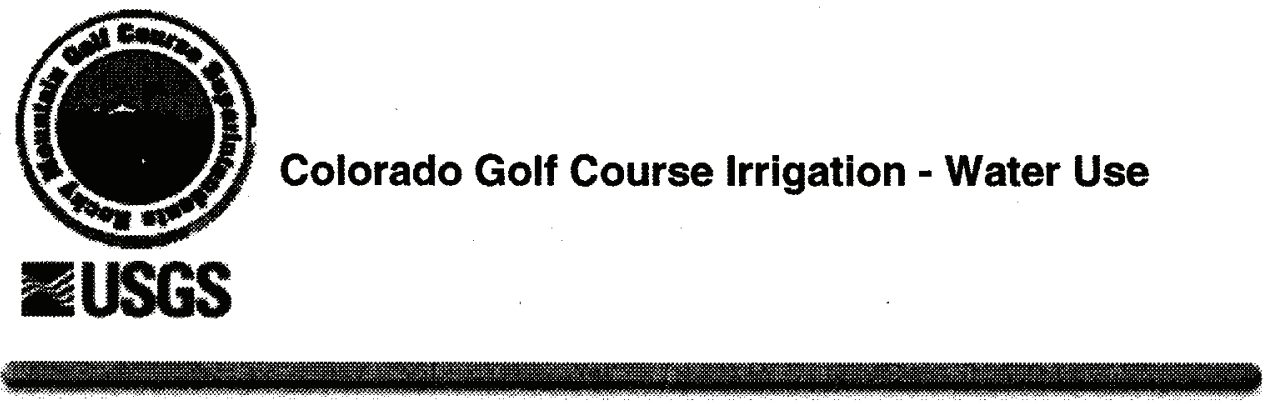

Ground Water Sources

8

Do you use Ground Water sources for irrigation?

(28s) (2.09)

SUBMIT

Survey Page 5

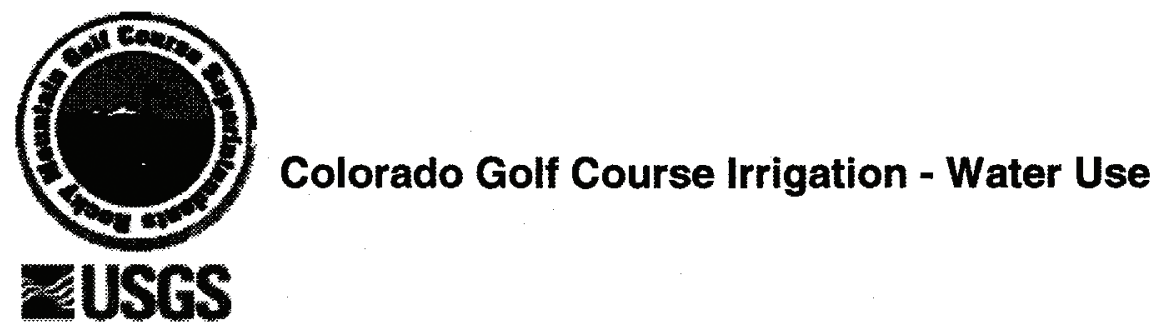

Groundwater Source(s) - (Enter up to four ground water sources) 
9

Ground Water Source 1:

Number of Wells:

Aquifer Name:

Amount (total

gallons used in

2005 or specify

units):

10

Above Source is:

- Primary

Secondary

( Tertiary

11

Ground Water Source 2:

Number of Wells:

Aquifer Name:

Amount (total gallons used in 2005 or specify units):

12

Above Source is:

( Primary

- Secondary

- Tertiary

13

Ground Water Source 3: 
Number of Wells:

Aquifer Name:

Amount (total

gallons used in

2005 or specify

units):

14

Above Source is:

- Primary

C Secondary

* Tertiary

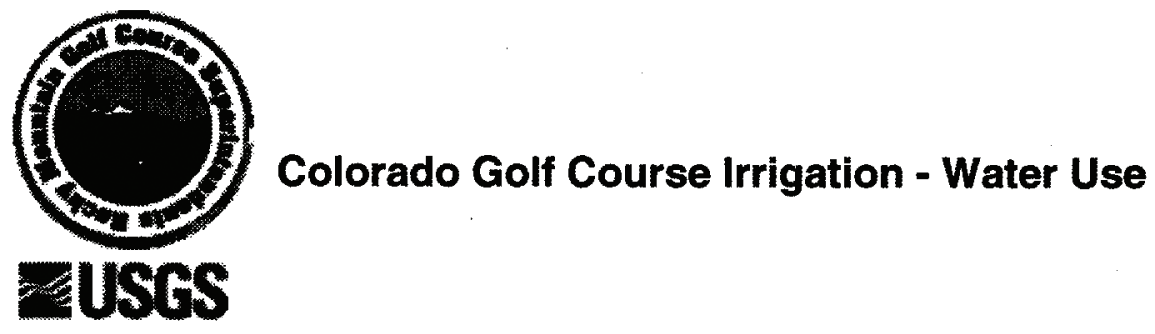

Public Supply Water Sources

15

Do you use public supply water - water from a municipal/community water supplier for irrigation? 
Public supply water - If you purchase potable water from a municipal/community water supplier(s) please provide water supplier name, county location and amount.

16

Public Water Supplier Information:

Public Water

Supplier 1:

County location of

Public Water

Supplier:

Amount (total gallons used in 2005 or specify units):

17

Above Source is:

(1) Primary

- Secondary

(6) Tertiary 
Public Water Supplier Information:

Public Water

Supplier 2:

County location of

Public Water

Supplier:

Amount (total gallons used in 2005 or specify units):

19

Above Source is:

1) Primary

- Secondary

6 Tertiary

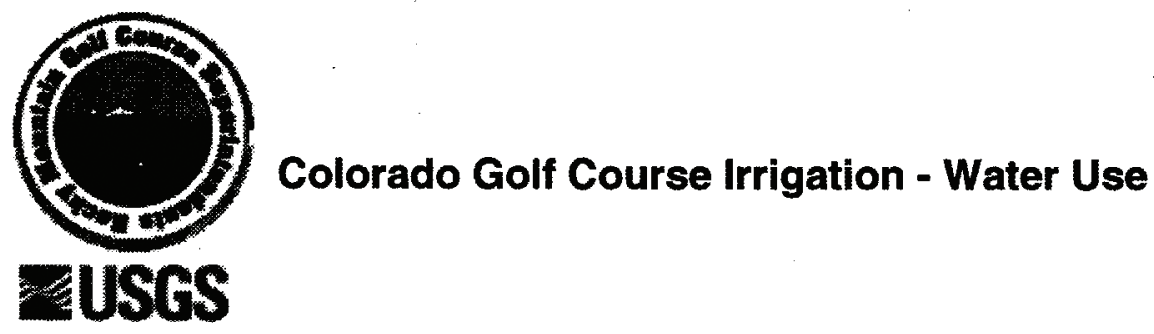

Reclaimed Water Sources

20

Do you use Reclaimed Water Sources - purchase reclaimed wastewater from a municipal/industrial source for irrigation? 


\section{suamit}

Survey Page 9

\section{Colorado Golf Course Irrigation - Water Use}

\section{EUSGS}

Reclaimed Sources - If you purchase reclaimed wastewater from a municipal/industrial source(s), please provide the water supplier name, County location and amount. (Reclaimed Wastewater is wastewater that is not returned to a stream, but is used for some other purpose like irrigation.)

21

Reclaimed Water Supplier Information:

Name of Supplier

1:

County location of

Reclaimed Water

Supplier:

Amount (total gallons used in 2005 or specify units):

22

Above Source is:

Primary

Secondary

Tertiary 
23

Reclaimed Water Supplier Information:

Name of Supplier

2:

County location of

Reclaimed Water

Supplier:

Amount (total gallons used in 2005 or specify units):

24

Above Source is:

6 Primary

- Secondary

- Tertiary 


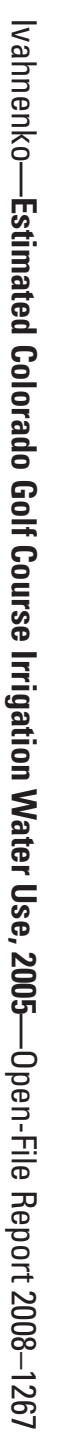

